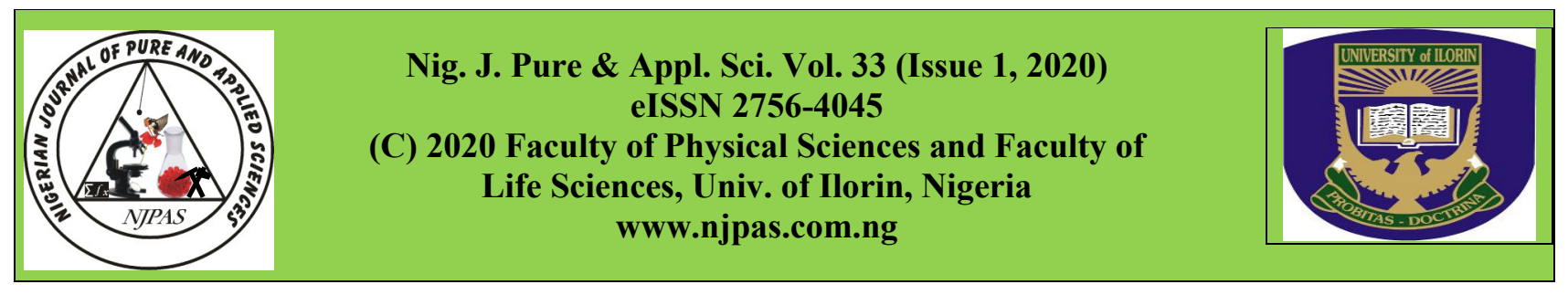

doi: http://dx.doi.org/10.48198/NJPAS/19.A13

\title{
Evaluation of cysteine-stabilised peptide fraction of aqueous extract of Morinda lucida leaf for hepatotoxic effects in mice
}

${ }^{1}$ Department of Biochemistry, Faculty of Life Sciences, University of Ilorin, Ilorin, Nigeria.

${ }^{2}$ Department of Biochemistry, Ondo State University of Medical Sciences, Ondo, Nigeria.

\section{ABSTRACT}

Cysteine-stabilised peptide fraction of the aqueous extract of Morinda lucida leaf has been reported to exert diverse biological activities, but its effects on the liver have not been evaluated. This study was carried out to evaluate the effects of cysteine-stabilised peptide fraction (CSPF) of aqueous extract of Morinda lucida leaf on selected liver function indices in mice. Sixty mice were randomly divided into six groups of ten mice each. Mice in group A (control) were orally administered 5\% DMSO while mice in groups B, C, D, E and F were orally administered $31.25,62.5,125,250$ and $500 \mathrm{mg} / \mathrm{kg}$ body weight of CSPF respectively. Half of the mice in the groups received the respective doses of CSPF for 7 days while the other half received them for 28 days, after which selected liver function indices in the serum and liver of the mice were determined. The results revealed that plasma alkaline phosphatase, gamma glutamyl transferase and glutamate dehydrogenase activities and plasma albumin, globulin, total bilirubin and conjugated bilirubin concentrations were not significantly $(\mathrm{P}>0.05)$ altered after 7 and 28 days of CSPF administration at all doses compared to controls. However, liver alanine aminotransferase (ALT) activity was significantly reduced $(\mathrm{p}<0.05)$ at doses of CSPF higher than $125 \mathrm{mg} / \mathrm{kg}$ body weight, with no corresponding alteration in serum ALT activity after 28 days of administration compared to controls. Thus, prolonged administration of high doses of CSPF may adversely affect the glucose-alanine cycle in the liver which is very important for glucose homeostasis during fasting.

Keywords: Cysteine-stabilised peptides, Morinda lucida, Leaf, Liver, Toxicity

\section{Introduction}

Medicinal plants are often used for the treatment of different ailments, with an estimated $80 \%$ of the population depending on this treatment option globally (Polasa and Nirmala, 2003). This is a very widespread practice in Africa, especially in the rural communities. The acclaimed efficacies of many of these herbal remedies have been scientifically authenticated (Adebayo and krettli, 2011). One of such medicinal plants used for the treatment of various diseases in West Africa is
Morinda lucida Benth (Rubiaceae). It is a rainforest tree called Brimstone tree. It is called Oruwo by the Yoruba people of South-western Nigeria. In Ghana, it is known as Twi, Kònkròmà or Ewe amake, while it is known as Ewe amake or Atak ake in Togo (Dalziel, 1937). Morinda lucida is a popular medicinal plant in Nigeria, where the decoction of its leaf is used for the treatment of malaria, typhoid fever, diabetes and gonorrhoea 
(Adesida and Adesogan, 1972; Makinde and Obih, 1985).

Recent studies have shown that the leaf of this plant expresses small linear cysteine-stabilised peptide (Adewole and Adebayo, 2017), a class of

Page | 3697 peptides currently attracting research attention because of their different biological activities. Examples of such biological activities include anticancer (Gerlach et al., 2010; Nguyen et al., 2012), insecticidal (Jennings et al., 2001), immunomodulatory (Gründemann et al., 2013), uterotonic (Gran, 1973; Koehbach et al., 2013), haemolytic (Henriques et al., 2011) and anti-HIV (Chen et al., 2005) activities. Recently, the cysteine-stabilised peptide fraction (CSPF) from Morinda lucida leaf was reported to exhibit antimalarial and antioxidant activities in mice (Adebayo et al., 2017). Adewole et al. (2017) reported that CSPF did not alter haematological parameters but reduced atherogenic index in mice. Moreover, CSPF did not adversely affect the osmoregulatory function of mouse kidney, though it adversely affected uric acid metabolism after prolonged administration in mice (Adewole and Adebayo, 2018). However, the toxic effects of CSPF obtained from Morinda lucida leaf on the liver have not been evaluated. This study was, therefore, embarked on to evaluate the hepatotoxicity of aqueous extract of Morinda lucida leaf in mice.

\section{Materials and Methods Chemicals}

Methanol and dichloromethane were purchased from Merck Pharmaceutical Company, Darmstadt, Germany; trifluoroacetic acid and acetonitrile were products of Sigma Chemical Company, St. Louis, Mo, USA. Carbon 18 medium was a product of Phenomenex, Aschaffenburg, Germany. Tris- $\mathrm{HCl}, \alpha$-ketoglutarate, ammonium chloride, reduced nicotinamide adenine dinucleotide and ethylene-diaminetetraacetic acid were purchased from BDH Chemicals Limited, Poole England. Kits for biochemical parameters were from Randox Laboratory Limited, United Kingdom.

\section{Plant Material}

Morinda lucida leaves were collected on the campus of the University of Ibadan, Ibadan, Oyo State, Nigeria, on $22^{\text {nd }}$ September, 2014. They were identified and authenticated at the Forestry Research Institute of Nigeria, Ibadan, Oyo State, Nigeria, where a voucher specimen was deposited (FHI: 110187).

\section{Animals}

Sixty adult Swiss albino mice were obtained from the small Animal Holding Unit of the Department of Biochemistry, University of Ilorin, Ilorin, Nigeria.

\section{Ethical Approval}

The animals were treated in accordance with the ethical standards approved by the University of Ilorin Ethical Review Committee (UERC/ASN/2015/067) which complies with the Guide for the Care and Use of Laboratory Animals published by the US National Institute of Health (NIH publication No. 85-23, revised 1996).

\section{Preparation of Cysteine-stabilised Peptide fraction}

Cysteine-stabilised peptide fraction was prepared as described by Hellinger et al. (2013). Briefly, the leaves were air-dried, pulverised and $500 \mathrm{~g}$ of the powder was percolated in $6 \mathrm{~L}$ of dichloromethane/methanol mixture $(1: 1, \mathrm{v} / \mathrm{v})$ and left for $18 \mathrm{~h}$. The mixture was thereafter filtered using muslin cloth. Equal volume of double distilled water was added to the filtrate in a separating funnel, after which the upper aqueous layer was separated and concentrated using a rotary evaporator at $40{ }^{\circ} \mathrm{C}$ and then lyophilized (Gallenkhamp). The lyophilized aqueous extract was reconstituted in a distilled watertrifluoroacetic acid mixture (100:0.05, v/v) and then passed through $\mathrm{C}_{18}$ column (Phenomenex, 
Aschaffenburg, Germany) that had been preconditioned with methanol and activated with acetonitrile-distilled water mixture $(9: 1, \mathrm{v} / \mathrm{v})$. The peptide was eluted from the column by washing with increasing concentrations $(20 \%, 80 \%$, and

Page | 3698 100\%) of acetonitrile-distilled water mixture. The eluent from $80 \%$ acetonitrile-distilled water mixture was concentrated under pressure in a rotary evaporator at $40{ }^{\circ} \mathrm{C}$ and freeze-dried, giving a percentage yield of $0.5 \%$ and referred to as CSPF.

\section{Animal Handling}

The mice were acclamatized for two weeks under laboratory conditions of $12 \mathrm{~h}$ light/dark cycle and room temperature $\left(28-30{ }^{\circ} \mathrm{C}\right)$ and were allowed free access to commercial pelletized feed (Ladoke Akintola Growers Mash, Nigeria) and water ad libitum.

\section{Administration of Cysteine-Stabilised Peptide fraction}

Sixty adult Swiss mice were randomly divided into six groups with ten animals in each group. Animals in group A served as the control and were orally administered 5\% dimethyl sulphoxide (DMSO) while animals in groups B, C, D, E and F were orally administered $31.25,62.5,125,250$ and $500 \mathrm{mg} / \mathrm{kg}$ body weight of CSPF respectively. Half of the mice in the groups received the respective doses of CSPF for 7 days while the other half received them for 28 days.

\section{Sample Collection and Preparation}

Five of the mice in each group were sacrificed after 7 days of CSPF administration while the remaining five were sacrificed after 28 days of CSPF administration by slight diethyl ether anaesthesia. Venous blood from the neck, initially cleared of fur, was collected into heparin bottles for biochemical analyses. The heparinised blood samples were centrifuged at $1000 \mathrm{rpm}$ for $10 \mathrm{~min}$ in an Eppendorf $5804 \mathrm{R}$ refrigerated centrifuge (Eppendorf AG, Harmburg, Germany) and the plasma was aspirated into plain sample bottles and kept frozen for biochemical analysis. The mice were carefully dissected and the liver of each mouse excised, cleaned of blood and weighed. The liver samples were homogenised in ice-cold 0.25 $M$ sucrose solution $(1: 5 \mathrm{w} / \mathrm{v})$; the homogenates were centrifuged at $10,000 \mathrm{~g}$ for $4 \mathrm{~min}$ in a Beili Shidaibeili GTR16-2 refrigerated centrifuge (Beijing Era Beili Centrifuge Co. Ltd., Beijing, China) and the supernatants were pipetted out and used for biochemical analysis. Sections from each liver were also fixed in $10 \%$ formalin for histopathological studies.

\section{Biochemical Analyses}

Total protein concentration was determined by the method of Gornall et al. (1949). Plasma albumin concentration was determined as described by Doumas et al. (1997) while plasma globulin concentration was estimated by subtracting plasma albumin concentration from plasma total protein concentration. Concentrations of total bilirubin and conjugated bilirubin in the plasma were determined as described by Winsten and Cehely (1968). The activities of aminotransferases and alkaline phosphatase (ALP) were determined by the methods of Reitman and Frankel (1957) and Wright et al. (1972) respectively. Determination of the activities of gamma-glutamyltransferase (GGT) and lactate dehydrogenase was carried out by the methods of Szasz (1969) and Wroblewski and La Due (1955) respectively while glutamate dehydrogenase activity (GDH) was determined by the method described by Shimizu et al. (1979).

\section{Histopathological studies}

The histopathological studies on the liver were carried out by the method described by Krause (2001). Briefly, the liver was fixed in $10 \%$ formalin for $24 \mathrm{~h}$. It was then dehydrated using increasing grades of ethanol to absolute ethanol and fixed in paraffin wax. Sections, $5 \mu \mathrm{m}$, were cut on a microtome and stained in aqueous dyes. Balsam mounting medium was added to the liver 
sections, thin glass cover slips were placed on the mounting medium and underlying tissue sections were allowed to dry, after which they were observed under the microscope (x 400 magnification) and the photomicrographs were Page | 3699 taken in a bright field.

\section{Statistical analysis}

The data are presented as Means \pm standard error of mean (SEM). Data were analysed using oneway ANOVA and Dunnett's test using SPSS 16.0 computer software package (SPSS Inc. Chicago, IL, USA). Differences at $\mathrm{p}<0.05$ were considered significant. Graphs were generated using GraphPad Prism 6 software (GraphPad Software, California, USA).

\section{Results}

The results revealed that there was no significant $(p>0.05)$ alteration in the liver-body weight ratios of mice at all doses of CSPF after 7 and 28 days of administration compared to controls (Table 1).
Also, CSPF, at all doses administered, had no significant $(p>0.05)$ effect on total protein, albumin, globulin, total and conjugated bilirubin concentrations in the plasma of mice after 7 and 28 days of administration compared to controls (Tables 2 and 3). From the results, there was no significant $(p>0.05)$ change in liver and plasma ALP, GGT, GDH and AST activities at all doses after 7 and 28 days of CSPF administration compared to controls (Fig. 1-4). There was significant increase $(p<0.05)$ in plasma ALT activity at $500 \mathrm{mg} / \mathrm{kg}$ body weight of CSPF, with no significant change $(p>0.05)$ at other doses after 7 days of administration and at all doses after 28 days of administration compared to controls (Fig. 5). CSPF significantly reduced $(\mathrm{p}<0.05)$ liver ALT at doses higher than $125 \mathrm{mg} / \mathrm{kg}$ body weight after 28 days of administration, with no significant change $(p>0.05)$ at all doses after 7 days of administration compared to controls (Fig. 5). CSPF, at all doses administered, caused no structural alteration in the histology of the liver compared to controls (Fig. 6 and 7).

Table 1: Effects of cysteine-stabilised peptide fraction of aqueous extract of Morinda lucida Leaf on Liver-Body Weight Ratios of Mice after 7 and 28 days of Administration

\begin{tabular}{|c|c|c|}
\hline \multirow[t]{2}{*}{ Treatment } & \multicolumn{2}{|c|}{ Liver - Body Weight Ratio (\%) } \\
\hline & Day 7 & Day 28 \\
\hline Control (5\% DMSO) & $5.22 \pm 0.45^{\mathrm{a}}$ & $4.53 \pm 0.49^{a}$ \\
\hline $31.25 \mathrm{mg} / \mathrm{kg} \mathrm{b.w}$ & $4.71 \pm 0.39^{a}$ & $4.06 \pm 0.31^{\mathrm{a}}$ \\
\hline $62.5 \mathrm{mg} / \mathrm{kg} \mathrm{b.w}$ & $4.41 \pm 0.39^{\mathrm{a}}$ & $3.70 \pm 0.26^{\mathrm{a}}$ \\
\hline $125 \mathrm{mg} / \mathrm{kg} \mathrm{b.w}$ & $5.18 \pm 0.51^{\mathrm{a}}$ & $3.96 \pm 0.19^{\mathrm{a}}$ \\
\hline $250 \mathrm{mg} / \mathrm{kg} \mathrm{b.w}$ & $4.31 \pm 0.15^{\mathrm{a}}$ & $3.95 \pm 0.20^{\mathrm{a}}$ \\
\hline $500 \mathrm{mg} / \mathrm{kg} \mathrm{b.w}$ & $4.35 \pm 0.41^{\mathrm{a}}$ & $4.37 \pm 0.24^{\mathrm{a}}$ \\
\hline
\end{tabular}

Values are means of 5 replicates \pm SEM. Means in the same column with the same superscripts are not significantly different $(\mathrm{p}>0.05)$. b.w-Body weight 
Table 2: Effects of cysteine-stabilised peptide fraction of aqueous extract of Morinda lucida leaf on concentrations of selected biomolecules in mouse plasma after 7 days of administration

\begin{tabular}{llllll}
\hline Treatment & $\begin{array}{l}\text { Total Protein } \\
\text { concentration } \\
(\mathbf{g} / \mathbf{L})\end{array}$ & $\begin{array}{l}\text { Albumin } \\
\text { concentration } \\
(\mathbf{g} / \mathbf{L})\end{array}$ & $\begin{array}{l}\text { Globulin } \\
\text { concentrat- } \\
\text { ion }(\mathbf{g} / \mathbf{L})\end{array}$ & $\begin{array}{l}\text { Total bilirubin } \\
\text { concentration } \\
(\boldsymbol{\mu m o l} / \mathbf{L})\end{array}$ & $\begin{array}{l}\text { Conjugated } \\
\text { bilirubin } \\
\text { concentration } \\
(\boldsymbol{\mu m o l} / \mathbf{L})\end{array}$ \\
\hline $\begin{array}{l}\text { Control }(5 \% \\
\text { DMSO })\end{array}$ & $27.21 \pm 2.37^{\mathrm{a}}$ & $18.36 \pm 1.26^{\mathrm{a}}$ & $8.85 \pm 2.02^{\mathrm{a}}$ & $203.50 \pm 13.08^{\mathrm{a}}$ & $49.20 \pm 10.04^{\mathrm{a}}$ \\
$31.25 \mathrm{mg} / \mathrm{kg}$ & $28.78 \pm 3.24^{\mathrm{a}}$ & $17.24 \pm 1.66^{\mathrm{a}}$ & $11.53 \pm 4.29^{\mathrm{a}}$ & $218.30 \pm 17.94^{\mathrm{a}}$ & $59.04 \pm 12.54^{\mathrm{a}}$ \\
b.w & & & & \\
$62.5 \mathrm{mg} / \mathrm{kg}$ b.w & $31.59 \pm 4.34^{\mathrm{a}}$ & $18.04 \pm 1.56^{\mathrm{a}}$ & $13.55 \pm 5.79^{\mathrm{a}}$ & $244.20 \pm 17.94^{\mathrm{a}}$ & $78.72 \pm 18.08^{\mathrm{a}}$ \\
$125 \mathrm{mg} / \mathrm{kg}$ b.w & $29.40 \pm 3.39^{\mathrm{a}}$ & $17.88 \pm 1.66^{\mathrm{a}}$ & $11.52 \pm 3.00^{\mathrm{a}}$ & $247.90 \pm 26.55^{\mathrm{a}}$ & $83.64 \pm 12.54^{\mathrm{a}}$ \\
$250 \mathrm{mg} / \mathrm{kg}$ b.w & $30.97 \pm 3.01^{\mathrm{a}}$ & $18.68 \pm 1.75^{\mathrm{a}}$ & $12.29 \pm 2.62^{\mathrm{a}}$ & $236.80 \pm 29.48^{\mathrm{a}}$ & $73.80 \pm 7.78^{\mathrm{a}}$ \\
$500 \mathrm{mg} / \mathrm{kg}$ b.w & $31.28 \pm 2.93^{\mathrm{a}}$ & $18.51 \pm 1.82^{\mathrm{a}}$ & $12.75 \pm 3.62^{\mathrm{a}}$ & $255.30 \pm 10.79^{\mathrm{a}}$ & $83.64 \pm 6.03^{\mathrm{a}}$ \\
\hline
\end{tabular}

Values are means of 5 replicates \pm SEM. Means in the same column with the same superscript are not significantly different $(\mathrm{p}>0.05)$. b.w-Body weight

Table 3: Effects of cysteine-stabilised peptide fraction of aqueous extract of Morinda lucida leaf on concentrations of selected biomolecules in mouse plasma after 28 days of administration

\begin{tabular}{|c|c|c|c|c|c|}
\hline Treatment & $\begin{array}{l}\text { Total Protein } \\
\text { concentration } \\
(\mathrm{g} / \mathrm{L})\end{array}$ & $\begin{array}{l}\text { Albumin } \\
\text { concentration } \\
(\mathrm{g} / \mathrm{L})\end{array}$ & $\begin{array}{l}\text { Globulin } \\
\text { concentration } \\
(\mathrm{g} / \mathrm{L})\end{array}$ & $\begin{array}{l}\text { Total bilirubin } \\
\text { concentration } \\
(\mu \mathrm{mol} / \mathrm{L})\end{array}$ & $\begin{array}{l}\text { Conjugated } \\
\text { bilirubin } \\
\text { concentration } \\
(\mu \mathrm{mol} / \mathrm{L})\end{array}$ \\
\hline $\begin{array}{l}\text { Control (5\% } \\
\text { DMSO) }\end{array}$ & $28.76 \pm 0.72^{a}$ & $12.89 \pm 1.17^{\mathrm{a}}$ & $15.87 \pm 1.86^{\mathrm{a}}$ & $215.53 \pm 0.93^{\mathrm{a}}$ & $86.72 \pm 4.64^{\mathrm{a}}$ \\
\hline $\begin{array}{l}31.25 \mathrm{mg} / \mathrm{kg} \\
\text { b.w }\end{array}$ & $28.53 \pm 1.13^{\mathrm{a}}$ & $16.15 \pm 0.69^{\mathrm{a}}$ & $12.38 \pm 0.65^{\mathrm{a}}$ & $212.29 \pm 1.58^{\mathrm{a}}$ & $87.33 \pm 1.23^{\mathrm{a}}$ \\
\hline $62.5 \mathrm{mg} / \mathrm{kg} \mathrm{b.w}$ & $29.19 \pm 1.13^{\mathrm{a}}$ & $16.66 \pm 0.35^{\mathrm{a}}$ & $12.53 \pm 1.12^{\mathrm{a}}$ & $218.30 \pm 1.69^{\mathrm{a}}$ & $97.17 \pm 8.55^{\mathrm{a}}$ \\
\hline $125 \mathrm{mg} / \mathrm{kg}$ b.w & $30.07 \pm 0.96^{\mathrm{a}}$ & $17.31 \pm 0.45^{\mathrm{a}}$ & $12.74 \pm 1.15^{\mathrm{a}}$ & $233.10 \pm 12.79^{\mathrm{a}}$ & $75.03 \pm 2.13^{\mathrm{a}}$ \\
\hline $250 \mathrm{mg} / \mathrm{kg}$ b.w & $29.80 \pm 0.97^{\mathrm{a}}$ & $15.77 \pm 1.12^{\mathrm{a}}$ & $14.04 \pm 1.39^{\mathrm{a}}$ & $230.33 \pm 6.34^{\mathrm{a}}$ & $81.80 \pm 3.23^{\mathrm{a}}$ \\
\hline $500 \mathrm{mg} / \mathrm{kg}$ b.w & $28.62 \pm 1.33^{\mathrm{a}}$ & $13.63 \pm 3.16^{\mathrm{a}}$ & $14.99 \pm 2.47^{\mathrm{a}}$ & $216.45 \pm 2.72^{\mathrm{a}}$ & $78.36 \pm 2.10^{\mathrm{a}}$ \\
\hline
\end{tabular}

Values are means of 5 replicates \pm SEM. Means in the same column with the same superscript are not significantly different $(\mathrm{p}>0.05)$. b.w-Body weight 
Page | 3701

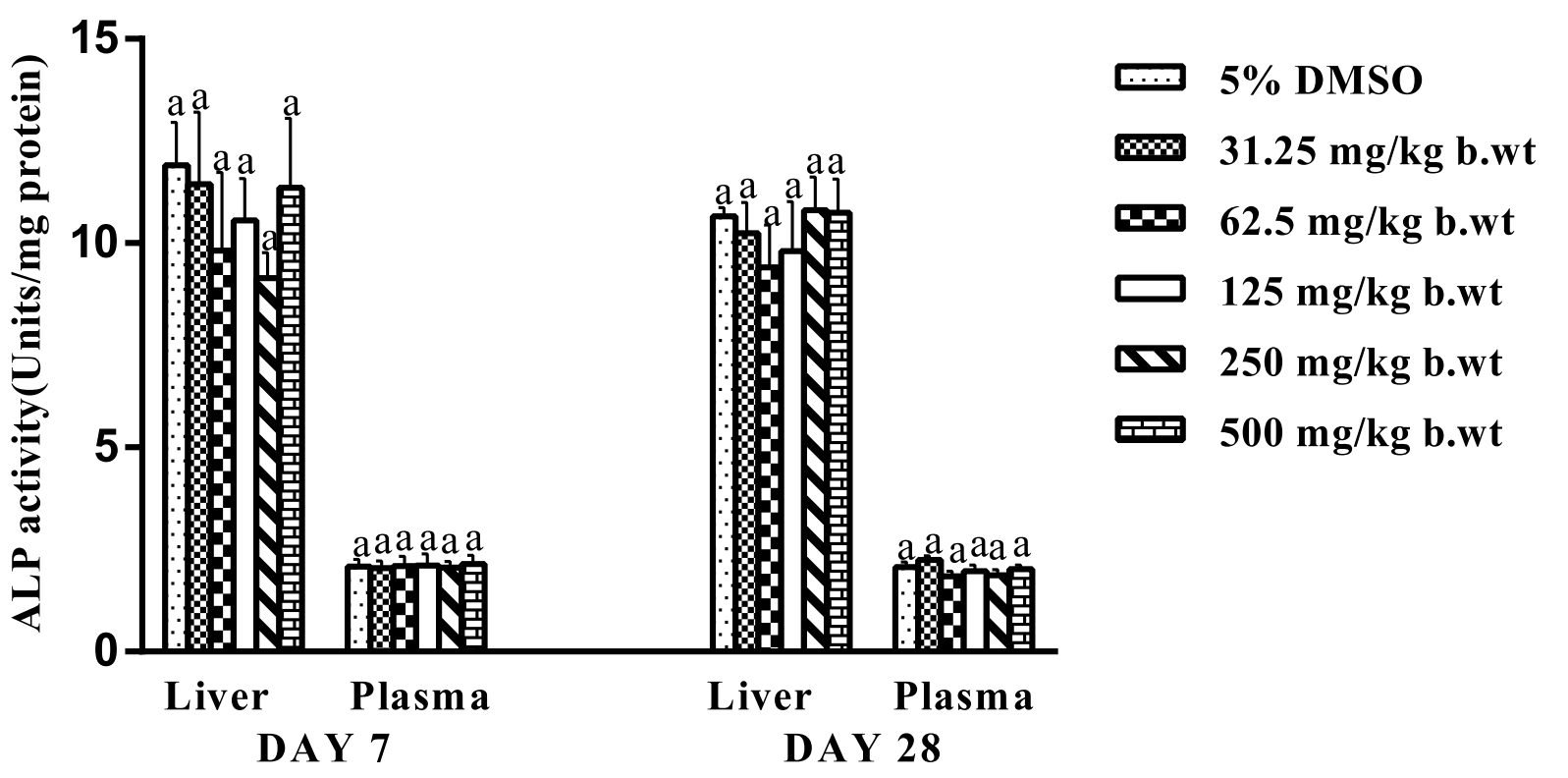

Fig. 1: Effects of cysteine-stabilised peptide fraction of aqueous extract of Morinda lucida leaf on the activities of alkaline phosphatase in the liver and plasma of mice after 7 and 28 days of administration. Values are means \pm SEM of 5 replicates. Bars for plasma/liver for each day with the same alphabet are not significantly different ( $>0.05$ ). b.wt-Body weight

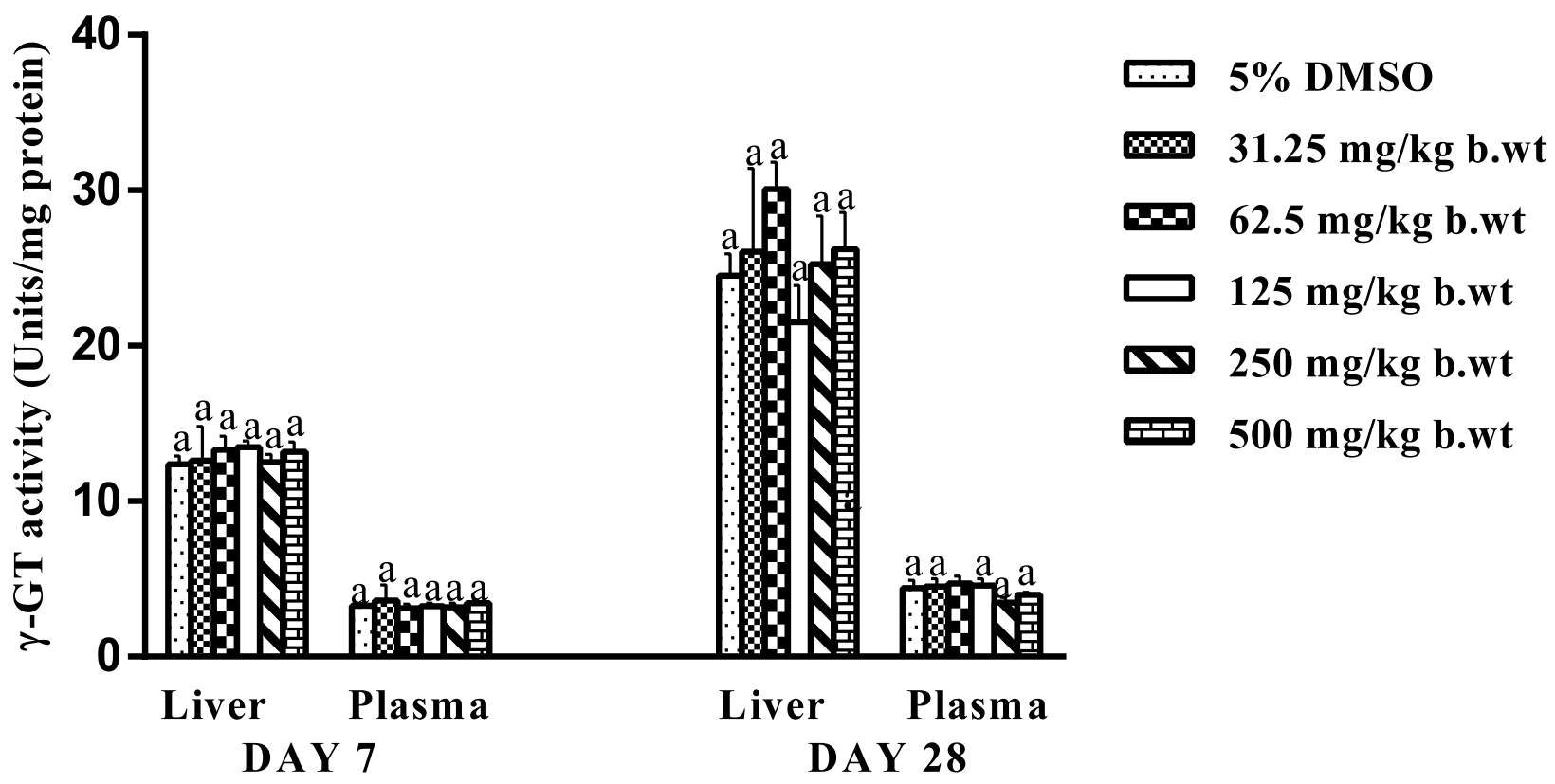

Fig. 2: Effects of cysteine-stabilised peptide fraction of aqueous extract of Morinda lucida leaf on the activities of gamma glutamyltransferase in the liver and plasma of mice after 7 and 28 days of administration. Values are means \pm SEM of 5 replicates. Bars for plasma/liver for each day with the same alphabet are not significantly different $(\mathrm{p}>0.05)$. b.wt-Body weight 


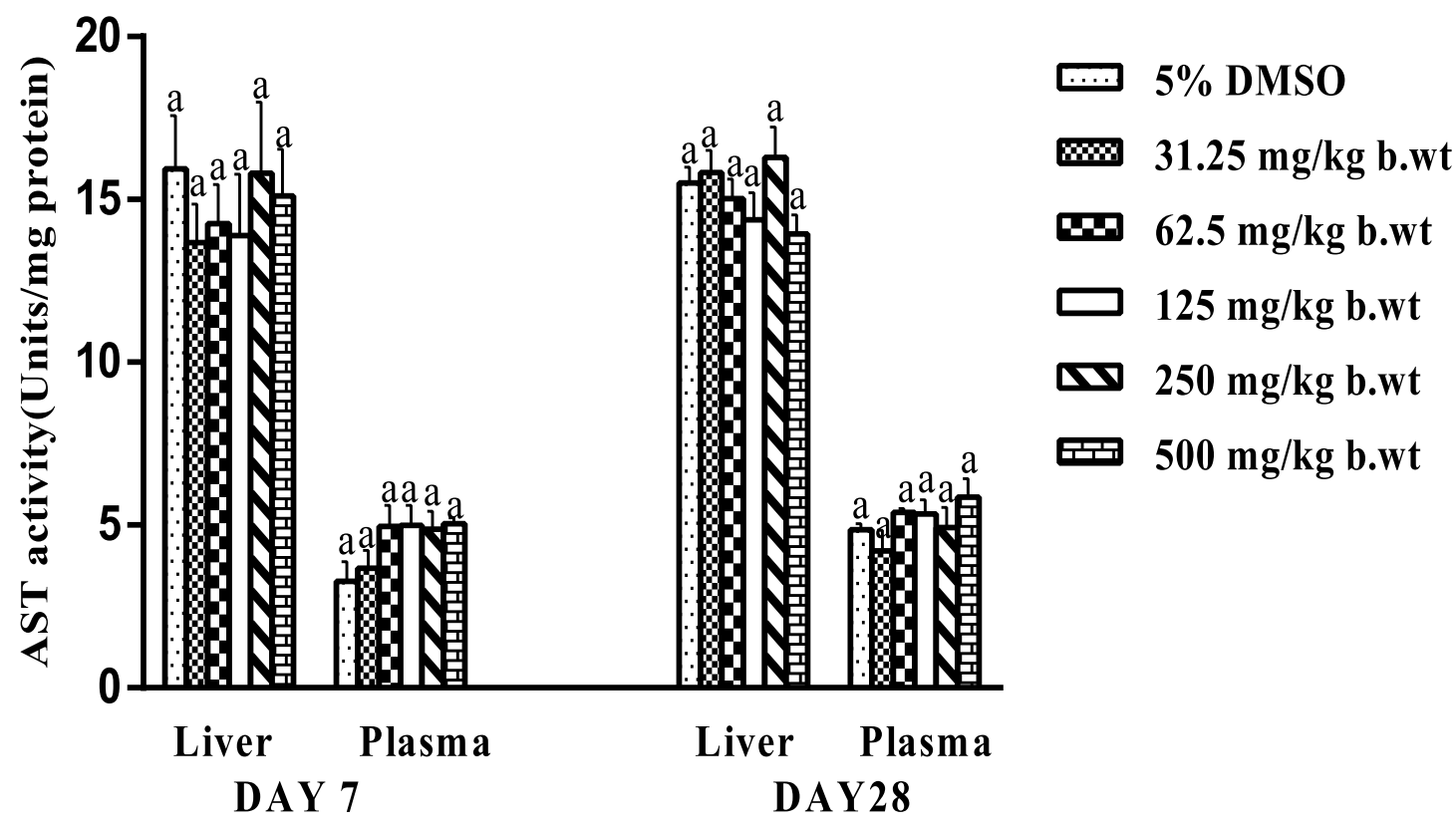

Fig. 3: Effects of cysteine-stabilised peptide fraction of aqueous extract of Morinda lucida leaf on the activities of aspartate aminotransferase in the liver and plasma of mice after 7 and 28 days of administration. Values are means \pm SEM of 5 replicates. Bars for plasma/liver for each day with the same alphabet are not significantly different (p>0.05). b.wt-Body weight

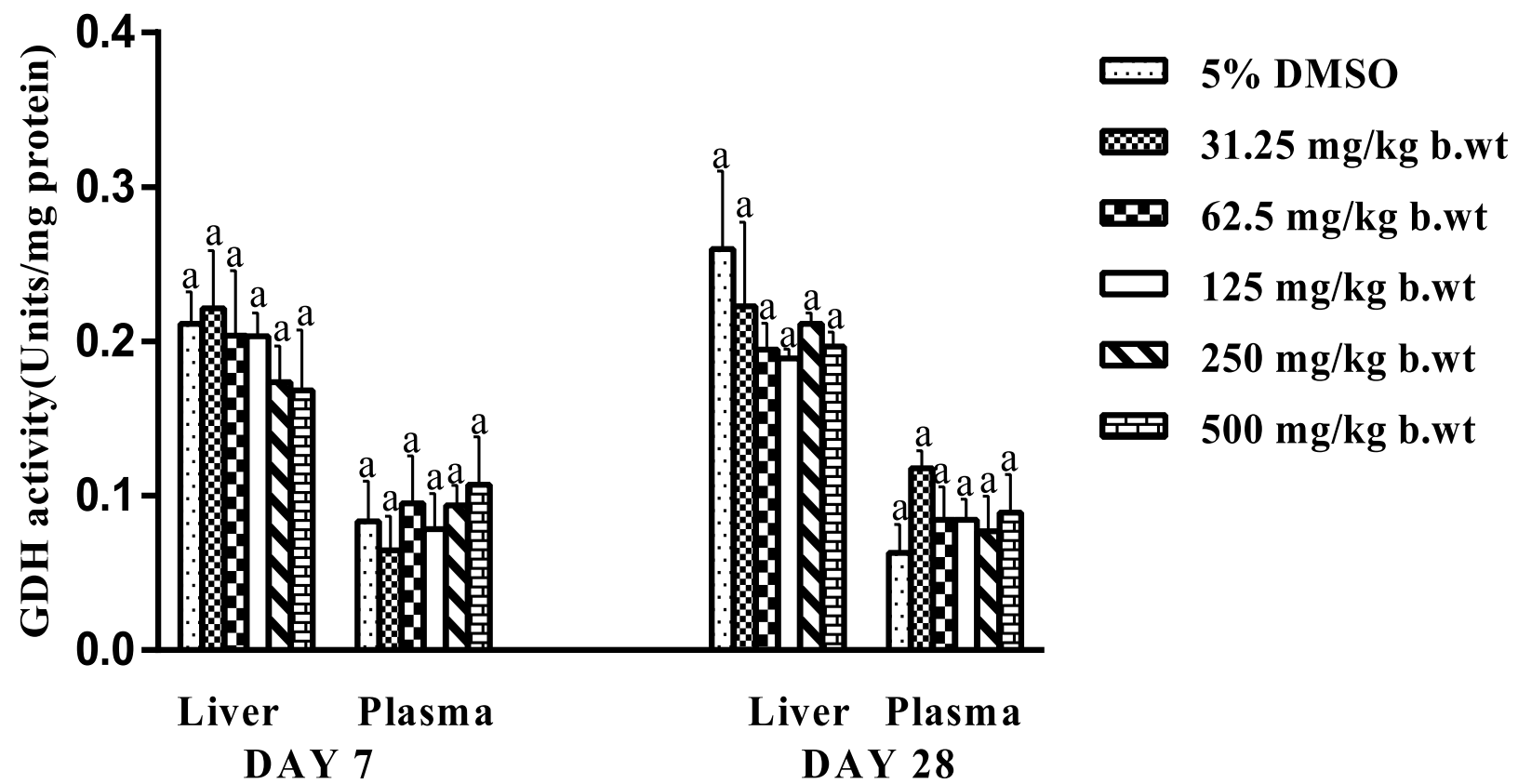

Fig. 4: Effects of cysteine-stabilised peptide fraction of aqueous extract of Morinda lucida leaf on the activities of glutamate dehydrogenase in liver and plasma of mice after 7 and 28 days of administration. Values are means \pm SEM of 5 replicates. Bars for plasma/liver for each day with the same alphabet are not significantly different ( $>0.05)$. b.wt-Body weight 


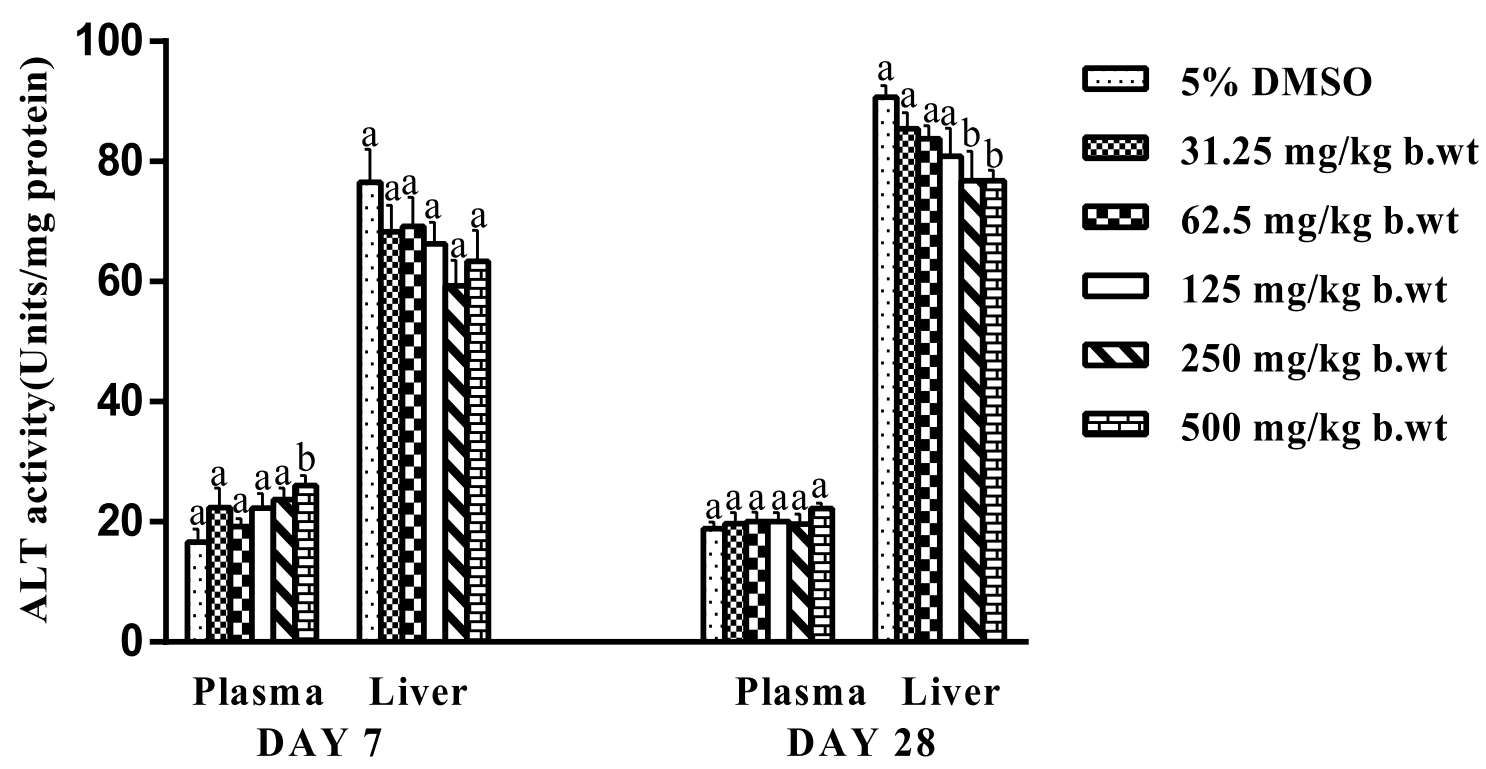

Fig. 5: Effects of cysteine-stabilised peptide fraction of aqueous extract of Morinda lucida leaf on the activities of alanine aminotransferase in plasma and liver of mice after 7 and 28 days of administration. Values are means \pm SEM of 5 replicates. Bars for plasma/liver for each day with different alphabets are significantly different $(\mathrm{p}<0.05)$. b.wt-Body weight
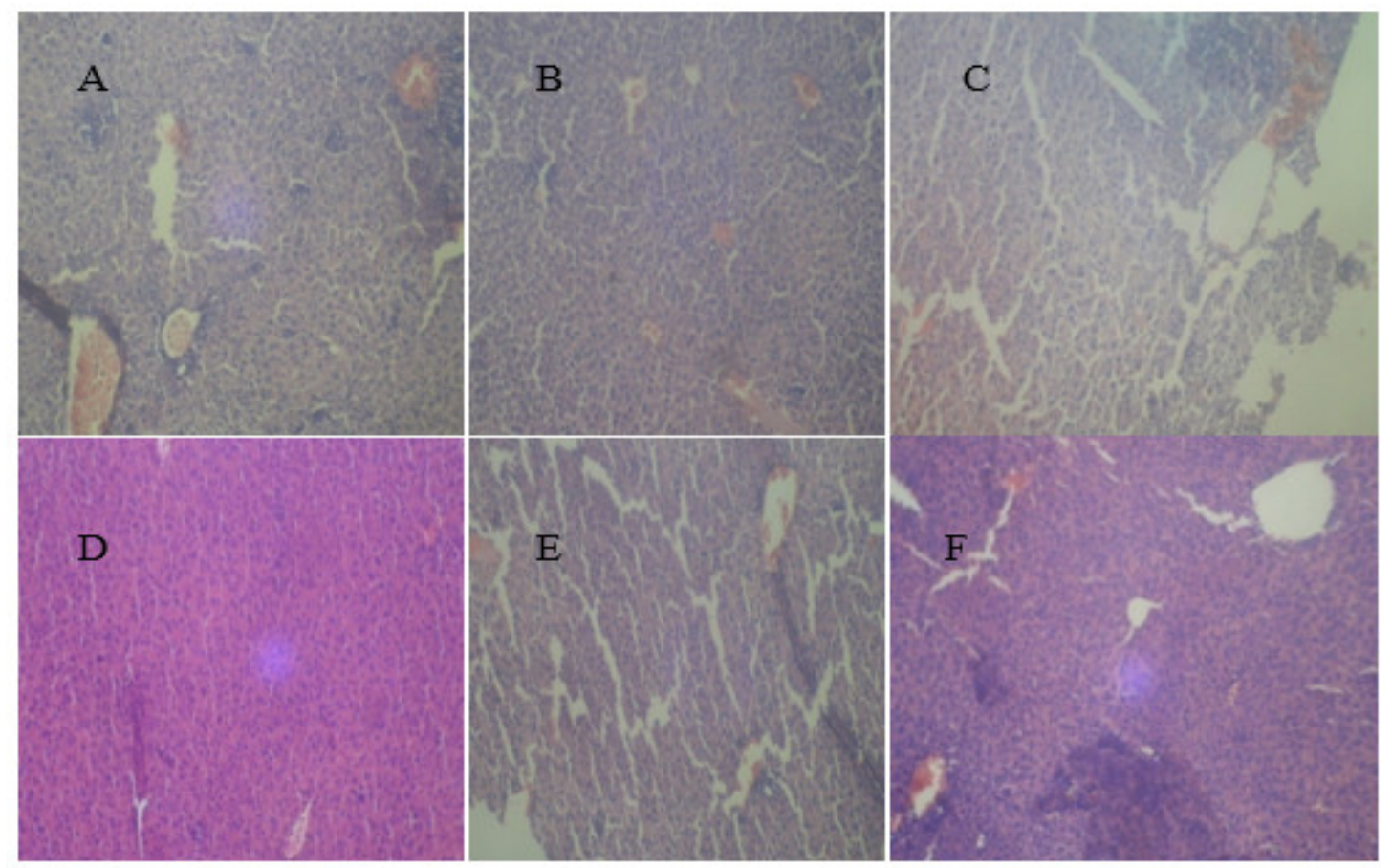

Fig. 6: Cross-section of mouse liver after 7 days of administration of cysteine-stabilized peptide fraction of aqueous extract of Morinda lucida leaf (x 400; H\&E). A: $5 \%$ DMSO; B: $31.25 \mathrm{mg} / \mathrm{kg}$ body weight; C: $62.5 \mathrm{mg} / \mathrm{kg}$ body weight; D: $125 \mathrm{mg} / \mathrm{kg}$ body weight; E: $250 \mathrm{mg} / \mathrm{kg}$ body weight; F: $500 \mathrm{mg} / \mathrm{kg}$ body weight. 

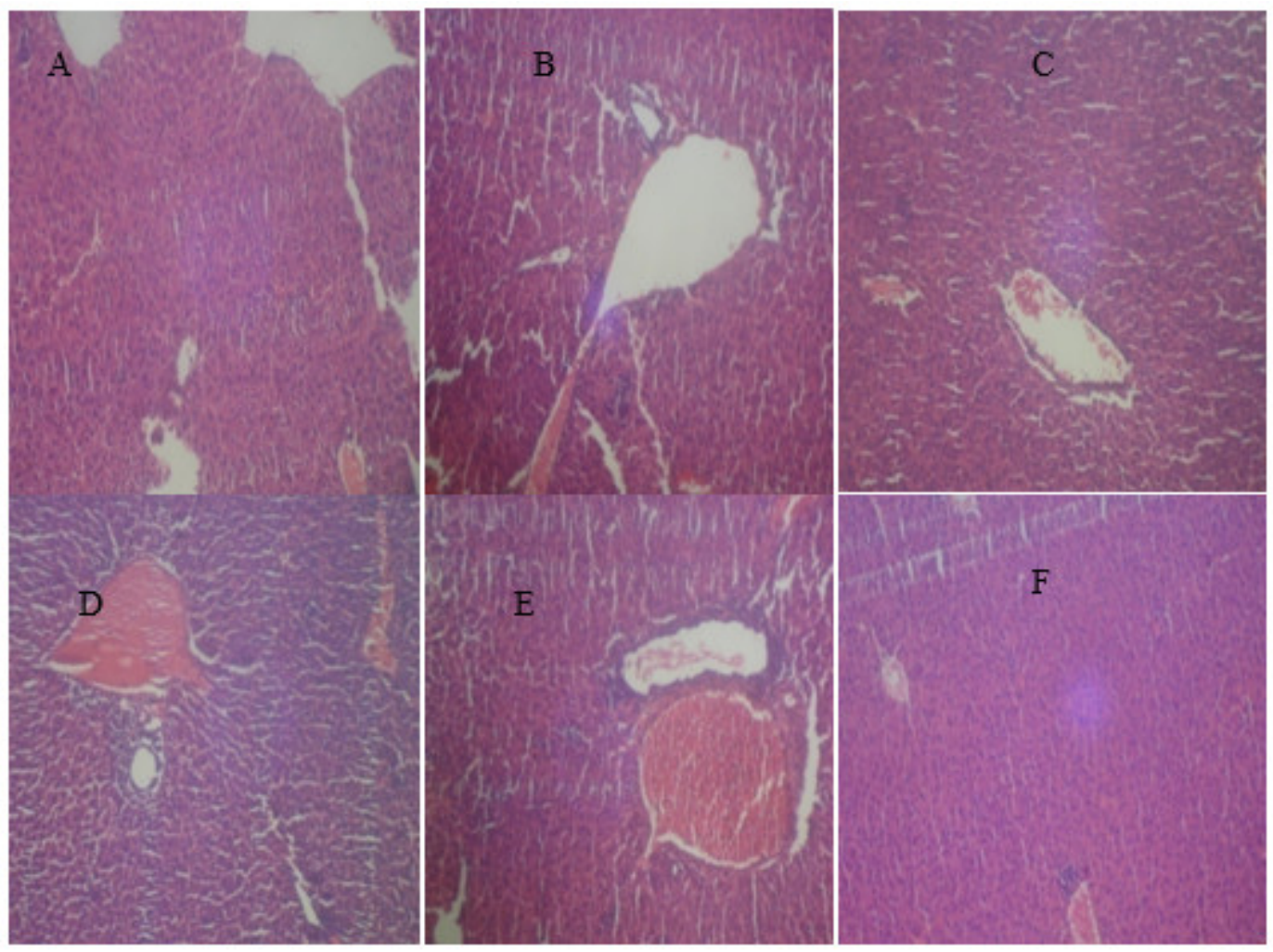

Fig. 7: Cross-section of mouse liver after 28 days of administration of cysteine-stabilized peptide fraction of aqueous extract of Morinda lucida leaf (x 400; H\&E). A: 5\% DMSO; B: $31.25 \mathrm{mg} / \mathrm{kg}$ body weight; C: $62.5 \mathrm{mg} / \mathrm{kg}$ body weight; D: $125 \mathrm{mg} / \mathrm{kg}$ body weight; E: $250 \mathrm{mg} / \mathrm{kg}$ body weight; F: $500 \mathrm{mg} / \mathrm{kg}$ body weight.

\section{Discussion}

One of the criteria set by the WHO for the use of any herb as drug is that it should not be toxic (WHO, 1978). This has necessitated the evaluation of natural products of plant origin for their toxicities. In this study, the effects of CSPF on selected liver function indices in mice were evaluated. Increase in organ-body weight ratio depicts inflammation while decrease in organbody weight ratio is an indication of cell constriction, resulting from necrosis (Moore and Dalley, 1999). CSPF administration for 7 and 28 days caused no change in liver-body weight ratio, suggesting that the fraction did not cause inflammation or necrosis in the liver. This is supported by the results of the histopathological studies which revealed that there was no observable difference in structural features of the liver of mice administered CSPF at all doses for 7 and 28 days compared to controls.

Determination of the activities of enzymes in tissues and body fluids is of great importance in the investigation and diagnosis of diseases (Malomo, 2000). These enzymes, including phosphatases, transferases and dehydrogenases, get into the blood when they leak from disrupted cells and damaged tissues (Zimmerman and Seeff, 1970). Alkaline phosphatase is used as a marker enzyme for the integrity of the plasma membrane and endoplasmic reticulum (Wright et al., 1972; Akanji et al., 1993). In this study, ALP activities in the plasma and liver were not significantly altered after 7 and 28 days of CSPF administration at all doses. This suggests that CSPF did not adversely affect plasma membrane integrity of liver cells, thus confirming the 
uncompromised organisation of the hepatic plates observed in the cross-section of the liver.

Glutamate dehydrogenase is found exclusively in the mitochondria and it is used to estimate the level of liver damage since it is released from necrotic cells (Panteghini and Bais, 2008). The fact that there was no significant change in the liver and plasma GDH activities suggests that consumption of CSPF did not cause hepatic necrosis or mitochondrial damage in the liver, further confirming the uncompromised integrity of the hepatic plates.

The significant increase in plasma ALT activity observed at the highest dose with no significant reduction in liver ALP and ALT activities after 7 days of administration suggests that the increase is not as a result of membrane damage in liver cells but as a result of activation of the enzyme in situ. Also, the reduced ALT activity in the liver at higher doses of the fraction after 28 days with no significant increase in plasma ALT activity suggests inactivation of the enzyme in situ or suppression of its synthesis in the liver. This may adversely affect the role of this enzyme in the glucose-alanine cycle (or Cahill cycle) in the liver. This cycle is responsible for the production of glucose for utilization in the muscle during shortage of glucose in the body (Fieng, 1973; Spydevold, 1976)

Plasma GGT is mainly from the hepatobiliary system; this makes its activity increased in hepatobiliary diseases. Although plasma GGT activity is the most sensitive enzymatic marker of hepatobiliary diseases, it is used in combination with other biochemical parameters, such as plasma ALP activity to confirm these diseases (Alan, 1995). From the results obtained in this study, administration of CSPF for 7 and 28 days did not significantly alter liver and plasma GGT activities at all doses. In conjunction with the plasma ALP activity which was not significantly altered, the result suggests that CSPF did not adversely affect the hepatobiliary system.

Plasma proteins (such as albumin and globulins) are mainly produced in the liver, with albumin being the most abundant. Albumin maintains the water balance in plasma, transports and stores biomolecules such as bilirubin, fatty acids, calcium and hormones like thyroxine. Albumin is also an endogenous source of amino acids. Hypoalbuminaemia has been linked with impaired albumin synthesis in the liver and liver diseases (Johnson, 2008). This condition adversely affects the physiological roles of albumin and will lead to oedema in tissues. Also, globulins are a heterogeneous complex mixture of protein molecules performing diverse functions in the body (Ganong, 2000). In this study, the concentrations of plasma total protein, albumin and globulins were not significantly altered by the administration of CSPF at all doses for 7 and 28 days compared to controls, suggesting that the synthetic function of the liver was not adversely affected by CSPF (Nicholson et al., 2000). This also suggests that the roles of these plasma proteins in the maintenance of blood osmotic pressure, transport of nutrients, defense, coagulation processes and buffering of blood $\mathrm{pH}$ were not adversely affected by CSPF.

Bilirubin is obtained from the catabolism of haemoglobin in the liver; it is conjugated with glucuronic acid in the liver to form a soluble compound. Conjugated bilirubin is secreted into the bile duct where it is excreted into the gastrointestinal tract. High plasma levels of unconjugated bilirubin indicate increased haemolysis or impairment in the conjugation of bilirubin in the liver (Ohkubo, 1994). Administration of CSPF for 7 and 28 days did not significantly change plasma levels of total bilirubin and conjugated bilirubin, suggesting that CSPF at the doses investigated had no adverse effect on the conjugation of bilirubin in the liver and secretion of conjugated bilirubin 
into the bile duct. It also suggests that it did not cause haemolysis after prolonged administration.

\section{Conclusion}

Consumption of cysteine-stabilised peptide fraction of aqueous extract of Morinda lucida leaf at high doses may impair glucose-alanine cycle in the liver of subjects, thereby adversely affecting glucose homeostatsis during fasting. In order to possibly get rid of this adverse effect, further purification of the peptide fraction to isolate the specific peptides with the reported pharmacological activities is required.

\section{Conflicts of Interest}

The authors declare that they have no conflicts of interest.

\section{References}

Adebayo, J. O. and Krettli, A. U. (2011). Potential antimalarials from Nigerian plants: A review. Journal of Ethnopharmacology, 133; 289-302.

Adebayo, J. O., Adewole, K. E., and Krettli, A. U. (2017). Cysteine-stabilised peptide extract of Morinda lucida (Benth) leaf exhibits antimalarial activity and augments antioxidant defense system in P. berghei- infected mice. Journal of Ethnopharmacology, 207; 118128.

Adesida, G. A. and Adesogan, E. K. (1972). Oruwal, a novel dihydroanthraquinone pigment from Morinda lucida Benth. Journal of the Chemical Society: Chemical Communications, 7; 405406.

Adewole, K. E. and Adebayo, J. O. (2017). Antioxidant defense system induced by cysteine-stabilized peptide fraction of aqueous extract of Morinda lucida leaf in selected tissues of Plasmodium berghei-infected mice. Journal of Integrative Medicine, 15(5); 388397.

Adewole, K. E., Igunnu, A. and Adebayo, J. O. (2018). Effects of cysteine-stabilised peptide fraction of aqueous extract of Morinda lucida leaf on selected cardiovascular diseases indices in mice. Indian Journal of Clinical Biochemistry, 34(4); 427-435.
Adewole, K. E. and Adebayo, J. O. (2018). Effects of cysteine-stabilized peptide fraction of Morinda lucida leaf on selected kidney function indices in mice. Tokai Journal of Experimental and Clinical Medicine, 43(3); 90-96.

Akanji, M. A., Olagoke, O. A. and Oloyede, O. B. (1993). Effect of chronic consumption of metabisulphite on the integrity of the rat kidney cellular system. Toxicology, 81; 173-179.

Alan, H. B. (1995). Tietz Clinical Guide to Laboratory Tests (4th edition). St. Louis, Missouri: WB Saunders Company.

Chen, B., Colgrave, M. L., Daly, N. L., Rosengren, K. J., Gustafson, K. R. and Craik, D. J. (2005). Isolation and characterization of novel cyclotides from Viola hederaceae. Journal of Biological Chemistry, 280(23); 22395-22405.

Dalziel, J. M. (1937). The useful plants of West Tropical Africa (1st edition). Crown Agents, London.

Doumas, B. T., Watson, W. A., Biggs, H. G. (1997). Albumin standards and the measurement of serum albumin with bromcresol green. Clinica Chimica Acta, 258(1); 21-30.

Felig, P. (1973). The glucose-alanine cycle. Metabolism, 22 (2); 179-207.

Ganong, W. F. (2000). Circumventricular organs: definition and role in the regulation of endocrine and autonomic function. Clinical and Experimental Pharmacology and Physiology, 27; 422-427.

Gerlach, S. L., Burman, R., Bohlin, L., Mondal, D. and Goransson, U. (2010). Isolation, characterization, and bioactivity of cyclotides from the micronesian plant Psychotria leptothyrsa. Journal of Natural Product, 73; 1207-1213.

Gornall, A. G., Bardawill, C. J. and David, M. M. (1949). Determination of serum proteins by means of the biuret reaction. Journal of Biological Chemistry, 177(2); 751-766.

Gran, L. (1973). Oxytocic principles of Oldenlandia affinis. Lloydia, 36(2); 174-178.

Gründemann, C., Thell, K., Lengen, K., GarciaKäufer, M., Huang, Y. H., Huber, R., Craik, D. J., Schabbauer, G. and Gruber, C. W. (2013). Cyclotides Suppress Human T-Lymphocyte 
Proliferation by an Interleukin 2-Dependent Mechanism. PLoS ONE, 8(6); e68016.

Hellinger, R., Köhbach, J., Fedchuk, H., Sauer, B., Huber, R., Gruber, C. W. and Gründemann, C. (2014). Immuno- suppressive activity of an aqueous Viola tricolor herbal extract. Journal of Ethnopharmacology, 151(1); 299-306.

Henriques, S. T., Huang, Y., Rosengren, K. J., Franquelim, H. G., Carvalho, F. A., Johnson, A., Sonza, S., Tachedjian, G., Castanho, M.A., Daly, N.L. and Craik, D. J. (2011). Decoding the membrane activity of the cyclotide Kalata B1: The importance of phosphatidyl ethanolamine phospholipids and lipid organization on hemolytic and anti-HIV activities. Journal of Biological Chemistry, 286(27); 24231-24241.

Jennings, C., West, J., Waine, C., Craik, D. and Anderson, M. (2001). Biosynthesis and insecticidal properties of plant cyclotides: The cyclic knotted proteins from Oldenlandia affinis. PNAS, 98(19); 10614-10619.

Johnson, M. (2008). Amino acids and proteins. In C. Burtis, E. Ashwood, and D. Bruns (Eds.), Tietz Fundamentals of Clinical Chemistry. Saunders-Elsevier, St. Louis, Missouri, USA, pp. 286-309.

Klaassen, C. D. and Eaton, D. L. (1996). Principles of Toxicology. In M. Amdour, J. Doull, \& C. D. Klaasen (Eds.), Casarett and Doull's Toxicology: The Basic Science of Poisons. McGraw-Hill, New York, USA, pp. 13-33.

Koehbach, J., Attah, A. F., Berger, A., Hellinger, R., Kutchan, T. M., Carpenter, E. J., Rolf, M., Sonibare, M. A., Moody, J. O., Wong, G. K., Dessein, S., Greger, H. and Gruber, C. W. (2013). Cyclotide discovery in Gentianales revisited-identification and characterization of cyclic cystine-knot peptides and their phylogenetic distribution in Rubiaceae plants. Peptide Science, 100(5); 438-452.

Krause, W. (2001). The art of examining and interpreting histologic preparations: A student handbook. (1st ed.). CRC Press, Florida, USA.

Makinde, J. and Obih, P. (1985). Screening of Morinda lucida leaf extract for antimalarial action on Plasmodium berghei berghei in mice. Afr J Med Med Sci., 14(1-2); 59-63.

Malomo, S. O. (2000). Toxicological implication of ceftriaxone administration in rats. Nigerian
Journal of Biochemistry and Molecular Biology, 15(1); 33-38.

Moore, K. L., and Dalley, A. F. (1999). Clinically orientated anatomy (4th edition). Lippincott Williams \& Wilkins, Philadelphia.

Nguyen, G. K. T., Lim, W. H., Nguyen, P. Q. T. and Tam, J. P. (2012). Novel cyclotides and uncyclotides with highly shortened precursors from Chassalia chartacea and effects of methionine oxidation on bioactivities. Journal of Biological Chemistry, 287(21); 1759817607.

Nicholson, J. P., Wolmarans, M. R. and Park, G. R. (2000). The role of albumin in critical illness. British Journal of Anaesthesia, 85(4); 599610.

Ohkubo, A. (1994). Bilirubin metabolism in liver cirrhosis. Nihon Rinsho, 52(1); 138-144.

Panteghini, M. and Bais, R. (2008). Enzymes. In C. Burtis, E. Ashwood, and Burns, D. (Eds.), Tietz Fundamentals of Clinical Chemistry. Saunders-Elsevier, St. Louis, Missouri, pp. 317-330.

Polasa, K. and Nirmala, K. (2003). Ginger: Its role in xenobiotic metabolism. ICMR Bulletin, 33(6); $57-62$.

Reitman, S. and Frankel, S. (1957). A colorimetric method for the determination of serum glutamic oxalacetic and glutamic pyruvic transaminases. American Journal of Clinical Pathology, 28(1); 56-63.

Shimizu, H., Kuratsu, T., and Hirata, F. (1979). Purification and some properties of glutamate dehydrogenase from Proteus inconstans. Journal of Fermention Technology, 57; 428433.

Spydevold, O. (1976). Sources of Carbon Skeleton of Alanine Released from Skeletal Muscle. Acta Physiologica Scandinavica. 93(3); 273-280.

Szasz, G. (1969). A kinetic photometric method for serum y-Glutamul transpeptidase. Clinical Chemistry, 15(2); 124-136.

WHO (1978). The promotion and development of traditional medicine: report of a WHO meeting.

Winsten, S. and Cehely, K. (1968). Serum bilirubin determination procedure. Clinical Chemistry, $14 ; 107$. 
Wright, P. J., Leathwood, P. D. and Plummer, D. T. (1972). Enzymes in rat urine: alkaline phosphatase. Enzymologia, 42(4); 317-327.

Wróblewski, F. and Ladue, J. S. (1955). Lactic dehydrogenase activity in blood. Experimental Page | 3708
Zimmerman, H. J. and Seeff, L. B. (1970). Enzymes in Hepatic Disease. In E. L. Coodley (Ed.), Diagnostic Enzymology. Lea \& Febiger, Philadelphia, pp. 1-38. 